\title{
THE ORIGINS OF CRIMINAL LIABILITY OF LEGAL PERSONS - A COMPARATIVE PERSPECTIVE
}

\author{
M. Catargiu
}

\author{
Magdalena Catargiu \\ Faculty of Law \\ "Alexandru Ioan Cuza" University, Iaşi, Romania \\ *Correspondence: Magdalena Catargiu, "Alexandru Ioan Cuza" University, 11 Boulevard \\ Carol I, 700506, Iaşi, Romania \\ E-mail:m_catargiu@yahoo.com
}

\section{Abstract}

The criminal liability of legal persons is an intrinsic reality of everyday life. However, this particular institution had a rather tumultuous evolution which is essential in understanding its organic mechanisms.

Through this study we aim to analyze the concept of criminal liability of the legal person from both diachronic and comparative perspective in order to determine the role of this fiction in contemporary legal systems. We shall focus on the legal framework in both European and Anglo-American systems. We also intend to identify the factors that have led to the consecration of criminal liability.

Keywords: legal personal, criminal liability, European regulations, Anglo-American legal system.

\section{Introduction}

In order to understand the inner mechanisms of the legal person, it is essential to analyze it both from the perspective of public law and of private law, as well.

One of the most controversial aspect regarding the criminal law institution is, undoubtedly, the liability of the entities. We perceive it in the same natural manner as the liability of individuals, neglecting, unfortunately, aspects of great importance that contribute to the configuration of legal entities as we known them today.

Romans were very attached to the idea that the legal person is very similar to the natural person. However, the legal person could not be held criminal responsible, fact enshrined also by the adagio societas delinquere non potest. Thus, Ulpian specifies that a municipium cannot be responsible for dolus, since it is a legal person ${ }^{1}$, i.e. a fictive entity. After all, the legal persons were the product of fiction, being actually nothing more than a legal metaphor.

However, some authors, especially Archille Mestre, asserted that the Romans considered legal persons capable of committing offenses and, in consequence, they could be punished. In support of its sentences, the author gives the example of the town Cheronea, against whom a criminal legal action had been formulated. This would lead to the idea that in Roman law, the criminal liability of legal persons was recognized ${ }^{2}$. In fact, some of the residents of the town, without the entire community being involved, killed Roman citizens. After trial, Cheronea had been exonerated.

In the Middle Ages, the liability of legal person remained a controversial matter. The general tendency has been to accept that legal person may also be criminal responsible. In the

\footnotetext{
${ }^{1}$ F. Streteanu, R. Chiriță, Răspunderea penală a persoanei juridice, C. H. Beck Publishing House, Bucharest, 2007, p. 4.

${ }^{2}$ F. Streteanu, R. Chiriță, op. cit., p. 5.
} 
context in which the Church`s role was predominantly, punishing legal person constituted a means of applying sanctions to those entities under public law in particular, which did not comply with the religious regulations. The penalty was excommunication. Pope Inocențiu the 6 th is the one of those who argued the criminal liability of the legal person. A supporter and an establisher, after some authors, of the theory of fiction, he rejected the idea that an imaginary creation can be held liable for committing a criminal offense, as it had no free will and no real existence. He argued that an universitas, because it was a creation without soul and body, which was not a part of the $\mathrm{Church}^{3}$, may not be punished by criminal provisions.

In Germanic law, both natural person, as well as legal person were recognized as being real subject of law. In the 7th century, there were established, as territorial units, centuries and curies. They were responsible for any criminal offenses committed on their territory ${ }^{4}$. Considering this, the basis of criminal sanctions was not guilt, but the consequences of the action. The penalty was actually a compensation, a restoration of the prejudice caused, more than a punishment per se.

In France, the criminal liability of moral person was consecrated by the Criminal Ordinance of 1670 and it had been applied until the French Revolution. The French code of 1810 has eliminated the criminal liability of legal persons, although it had been consecrated before the 8th century. But the new legislation was based on the realities of that historical times. After the French revolution, legal persons under private law had vanished due to the prohibition of freedom of association.

The criminal liability was vehemently criticized by the ultra vires doctrine supporters. The sense of the syntagm ultra vires is revealed by the expression beyond the powers. According to this theory, the legal person is entitled only to those legal rights which had been specifically conferred, therefore, a legal person`s capacity is limited to the specialization of its object of activity. It may act only in accordance with the purpose for which it was established. Criminal liability would imply that committing offences must be one of the statutory purposes. This is, without doubt, not possible, whereas the object of an association must be in accordance with the law and with the morality. The 9th century, in Great Britain, this concept has been adopted by the court in Ashbury Railway Carriage and Iron Co. v. Riche.

Before the Second World War, in Europe, despite the tradition of the Middle ages, the principle societas delinquere non potest continued to be applied. After the War, the judges of Nuremberg had not punished Germany, but the Nazi Party, which was also a legal person.

The Netherlands was the first European country to introduce the concept of criminal liability of moral person, in 1976. From the last decade of the 20th century, the majority of the member states of the old continent followed its example. Some countries, such as Sweden and Greece have refused the recognition and the consolidation of criminal liability of the legal person.

Germany has opted for administrative liability of collective entities. This implies that an offense must be related to individual - verbandsunrecht ${ }^{5}$. It is mandatory that the action is related to a legal obligation of the moral person and it has to have contributed to its enrichment. The doctrine is also known as the theory of the report of legal persons.

In France, criminal liability of moral person has been re-introduced by the Criminal code of 1994 and it is based on the theory of the identification of bodies and the representatives with the legal person. In accordance with article 121-2 of the Criminal code "moral persons, except the State, are responsible under criminal law [...] of the criminal offenses committed in their name or on their behalf, by their bodies or representatives. "(Les personnes morales, à l'exclusion de l'Etat, sont responsables pénalement [...] des infractions

\footnotetext{
${ }^{3}$ M. Lizee, De la capacite organique et des responsabilites delictulle et penale, McGill Law Journal, no. 41/1995, p. 5.

${ }^{4}$ Ibidem, p. 9.

5 Sofie Geeroms, La responsabilité pénale de la personne morale: une étude comparative, in Revue internationale de droit comparé, no. 3/1999, p. 545.
} 
commises, pour leur compte, par leurs organes ou représentants.). In other words, the governing bodies and the representatives shall be identified with a legal entity in all legal relations. Whenever a crime is committed by a person outside the entity, the criminal liability of the collective person is not possible. Also, an employee, if he is not part of the governing bodies or does not act as a representative of the moral person cannot attract, by his deed, the criminal liability of the entity. The above reasoning is founded on theory of liability by "rebound". According to this doctrine, in order to be criminal liable it is necessary the offense to have been committed by a natural person. The moral person is responsible only in the situation in which the offense has been performed by a body or a representative, in the name and on its behalf. The responsibility is, therefore, of conventional nature.

This doctrine follows the theory of functional liability, jurisprudential creation based on a fiction. The representatives of the entity cannot be held responsible for everything that is happening inside the legal person. They may be responsible only for those events regarding which they had a certain power or were their responsibilities. Therefore, committing a criminal offense shall be examined considering the functions carried out under the legal person`s activity. It is not punished the author of physical offense, but the one that was responsible, at the time of the offense, with the inspection or supervision ${ }^{6}$ of the activities carried out by the entity.

But, naturally, the legal person may not be subject of all offenses. As such, Article 121 paragraph (2) of the French Criminal Code stipulates that the legal person answers "in the cases provided for by law or regulation". The penalties applicable to the person legal are not the same with those for individual. These are limited provided by the law, for instance, the fine, the dissolution, the prohibition of carrying out particular activities for a certain period.

A special solution was adopted by Malta. In the situation in which a criminal offense is presumed to have been committed by a legal person, all those who, at the time, were directors, managers and secretaries or occupied other similar positions or who have being fulfilling those functions, will be considered responsible for the criminal offense. The criminal liability of natural person is not active whenever he proves that he has no knowledge of the offense or that he has acted with due diligence to prevent the offence ${ }^{7}$. The raison of this solution is justified by the fact that legal person does not have a free will, therefore it is not likely to have criminal intentions. When the individual violates the legal regulations, whenever he is part of any decision-making bodies or of representation, he shall be responsible under criminal law.

In Romania, criminal liability of moral person was introduced by the Law no. 278/2006. The consecration this institution was due to the need for Romania to comply with European Union`s trend, as well as to respect the commitment assumed by ratifying international instruments and the recommendations of European Union in this respect.

In the anglo-american system of law, criminal liability of the legal person is indirect. Regarding the subjective side of the offence, the doctrine has formulated the identity theory. Thus, the behavior of the directors or of representatives of the legal person is that of the moral person itself.

The U.S.A. have been pioneers in consecrating the criminal liability of the legal person. This is rather surprising considering that the system of common law embraced the theory of fiction. Until the 18th century, this concept had been rejected with uncharacteristic vehemence by the American courts. They considered that by regulating such institutions, ridiculous situations can occur, whereas some penalties may not be applicable only to natural persons. For instance, the legal person cannot be incarcerated.

\footnotetext{
${ }^{6}$ Sofie Geeroms, op. cit., p. 542.

${ }^{7}$ Gert Vermeulen, Wendy De Bondt, Charlotte Ryckman, Liability of Legal Persons for Offences in the E.U., Institute for International Research on Criminal Policy, European Commission, Maklu Publishers, Antwerpen, 2012, p. 23.
} 
In the 19th century, corporations began to develop. The industrial revolution phenomenon was amplifying. The new realities have imposed the dismissal of the principle societas delinquere non potest. The number of criminal allegations charges by the prosecutors against corporations was growing. Courts were convinced, in more and more causes, of their arguments. Common law was changing. The Congress had interpreted the concept of person within the meaning of including also corporations. Therefore, criminal law was applied to all persons. Corporations could be held criminal responsible. For instance, in 1901, New York Central Railroad has been accused of aggravated murder. A fire busted in its depot, where a considerable amount of dynamite was held, violating, therefore, the legal rules. The explosion which broke out killed 6 workers ${ }^{8}$.

Maintaining the institution of criminal liability of corporation for over two centuries in American law is, in many cases, justified by the particularities of the justice system. The defendant benefits from numerous and important procedural rights. As they are consecrated in the Constitution, the activity of prosecutors regarding hearing witnesses or discovering evidence is difficult. In case of offenses committed by the legal person, the prosecutors' situation is more time consuming. The confidentiality client-lawyer has been interpreted broadly by judges. Lawyers use, in most cases, means to slow down legal procedures, blocking the administration of evidence or to challenge the accusations in all procedural phases. By regulating the criminal liability of legal persons, there has been created an advantage of the prosecutors in the negotiations with corporate representatives. They may decide what evidence to administrate and if they drop off or not the charges. The corporation which collaborates with the accusation in the identification and the punishment of guilty natural persons, such as directors, managers, in most of the times, is no longer subject of sanctions. The institution`s aim is not to punish the legal person, but rather to determined it to cooperate with the prosecutors in catching those who are guilty ${ }^{9}$.

In Great Britain, a premise in consecrating the criminal liability of the legal person had been the modification, in 1899, of Interpretation Act by including within the concept of person legal entities as well. English courts, had been condemning legal persons from the very beginning of the 19th century for accusations of nuisance - the omission or the lack of compliance with legal provisions. In 1840, in the case The Queen v. Birmingham and Gloucester Railway, the latter had been convicted for failure to obey a legal order while it had been required to destroy a bridge. In 1844, in The Queen v. Great North of England Railway Co., the company had been sanctioned for that employees who did not repaired the damaged road due to the construction of a railway line ${ }^{10}$. The corporation was liable for someone else's deed as, according to the respondent theory, a legal person can be responsible for the offenses committed by an employee or an agent. Therefore, the company has the obligation to comply itself, as well as its employees, with the legal rules.

In Great Britain, two doctrines were fruitfully governing the criminal liability of moral persons: the objective and the subjective theories. The objective liability may be strict liability, in which it is relevant the personal offense and vicarious liability or liability for someone else's deed. The second form of liability is based on the idea of guilt, being a responsibility of subjective nature.

In the case of the first form, it does not appear to be necessary proving the guilt - mens $r e a$, whether it is intention, fault with or without provision, but it is mandatory to demonstrate one or all the elements of the action/inaction - actum rea. Vicarious liability, on the other hand, attacks the criminal liability for the crime committed by the person itself or by another

\footnotetext{
${ }^{8}$ W. S. Laufer, Corporate Bodies and Guilty Minds: The Failure of Corporate Criminal Liability, University of Chicago Press, 2006, p. 12.

${ }^{9}$ E. B. Diskant, Comparative Corporate Criminal Liability: Exploring the Uniquely American Doctrine Through Comparative Criminal Procedure, Yale Law Journal, no. 126/2008, pp. 128-132.

${ }^{10}$ Leonard Heschel Leigh, The Criminal Liability of Corporations and Other Groups, in Ottawa Law review, vol. 9/1977, p. 249.
} 
person who has acted with mens rea, for instance, the criminal responsibility of the moral person for a prohibited action committed by an employee ${ }^{11}$.

\section{Conclusions}

A factual situation does not generate legal effects until it is consecrated by legal provisions. Without being recognized by the law, the legal person does not legally exists. It remains, therefore, a fiction. By juridical recognition, the person gains rights and obligations.

In this context, the criminal liability of legal persons is, as Professor Valeriu M. Ciucă stated "a postmodern implausible fiction"12. The principle of personal criminal liability is not susceptible of extensive interpretations. The individual has a real existence, it is not a metaphor of the law. Its actions are determined by its own psychological processes. He is the one who, by fault or intentionally, commits offenses. In this regard, we have to notice that one of the raisons for ending the criminal prosecution is, according to the law, the death, and not the dissolving of the offender.

A legal entity is a collective body. It has rights and obligations, but cannot substitute the individual. Its will is assigned by the persons who compose or manage it, therefore, the legal person has no personal will. In some cases, these persons are different from the one who commits the offence, for instance, as a representative. There are, therefore, two wills which become confluent only in the plan of theory, both regarding "the interest of the legal person".

Furthermore, in the case of Romania, the consecration of criminal liability of entities has been the effect of the ratification of international instruments and the commitment to the European Union. So, the organic premises of this institution are missing.

In Europe, in the 20th century, when the criminal liability was recognized, premises that have determined the regulation of criminal liability of the legal person, did not longer exist. We believe that there is a need at least for the Romanian legislator to take return to its Roman legislative heritage, and dispense of this institution which is rather inconsistent.

\section{Bibliography:}

Gert Vermeulen, Wendy De Bondt, Charlotte Ryckman, Liability of Legal Persons for Offences in the E.U., Institute for International Research on Criminal Policy, European Comission, Maklu Publishers, Antwerpen, 2012;

E. B. Diskant, Comparative Corporate Criminal Liability: Exploring the Uniquely American Doctrine Through Comparative Criminal Procedure, Yale Law Journal, no. 126/2008;

F. Streteanu, R. Chiriță, Răspunderea penală a persoanei juridice, C. H. Beck Publishing House, Bucharest, 2007;

W. S. Laufer, Corporate Bodies and Guilty Minds: The Failure of Corporate Criminal Liability, University of Chicago Press, 2006;

Sofie Geeroms, La responsabilité pénale de la personne morale: une étude comparative, in Revue internationale de droit comparé, no. 3/1999;

V. M. Ciucă, Răspunderea penală a persoanei juridice - o ficțiune postmodernă neverosimilă, in Anuar, "Petre Andrei" University Iaşi, $8^{\text {th }}$ Tome /1998;

M. Lizee, De la capacite organique et des responsabilites delictulle et penale, McGill Law Journal, no. 41/1995;

Leonard Heschel Leigh, Strict and vicarious liability, Sweet and Maxwell Limited, London, 1982;

Leonard Heschel Leigh, The Criminal Liability of Corporations and Other Groups, in Otawwa Law review, vol. 9/1977.

\footnotetext{
${ }^{11}$ Leonard Heschel Leigh, Strict and vicarious liability, Sweet and Maxwell Limited, London, 1982, p.1.

${ }^{12}$ Valerius M. Ciucă, Răspunderea penală a persoanei juridice - o ficțiune postmodernă neverosimilă, in Anuar, Universitatea Petre Andrei, Tomul al VIII-lea / 1998, pp. 15 and ff.
} 